\title{
PRODUKSI FILM BIOMULSA DARI KLOBOT JAGUNG - LLDPE UNTUK APLIKASI DI BIDANG HORTIKULTURA
}

\section{THE PRODUCTION OF BIOMULCHING FILMS BASED ON CORN HUSK -LLDPE POLYMER FOR HORTICULTURAL APPLICATIONS}

\author{
Mersi Kurniati $^{1{ }^{*}}$, Akhiruddin Maddu' ${ }^{1)}$, dan Sidikrubadi Pramudito ${ }^{2)}$ \\ ${ }^{1)}$ Divisi Biofisika Departemen Fisika Fakultas Matematika dan Ilmu Pengetahuan Alam, Institut Pertanian Bogor \\ Kampus IPB Darmaga, Bogor, Jawa Barat, 16680, Indonesia \\ Email: mersikurniati@gmail.com \\ ${ }^{2}$ Divisi Teori Departemen Fisika Fakultas Matematika dan Ilmu Pengetahuan Alam ,Institut Pertanian Bogor 16680, Indonesia
}

Makalah: Diterima 10 Agustus 2018; Diperbaiki 29 Januari 2019; Disetujui 25 Maret 2019

\begin{abstract}
From a crop production perspective, plastic mulches can increase yields, extend the growing season, reduce weed pressure, increase fertilizer use efficiency, conserve soil moisture, and increase soil temperature. A major limitation of polyethylene mulch involves disposal of mulch material following use. Recently, biodegradable mulch films have been viewed as a more sustainable ecological alternative to plastic polyethylene mulch. In an effort to cope up with the severe and continuously growing agricultural plastic waste problem, biodegradable film was fabricate using natural waste (corn husk) as reinforcing agent and the film fabricated was used to produce biodegradable mulching fim (Biomulch). In this research, the biomulch of the corn husk and Linear Low Density Polyethylene (LLDPE) produced by extrusion and calandering method with a width of 25 $\mathrm{cm}$ has been made. Biomulches were made of corn husksby concentration of: 5, 10 and 15\% (\% w/w). Proximate and fiber analysis were conducted to determine the composition of corn husks. The biomulches were produced were analyzed by mechanical, thermal, microstructure, morphological, and functional group properties. The results showed that the mechanical characteristics decreased with the addition of cornhusk concentration on biomulches, and concentration $5 \%$ had the highest mechanical characteristics with tensile strength of 14.52 $\mathrm{MPa}$, elongation at break of $358.10 \%$ and modulus of elasticity of $0.37 \mathrm{GPa}$.
\end{abstract}

Keywords: biomulches, corn husks, calandering, LLDPE

\section{ABSTRAK}

Menurut perspektif produksi tanaman, mulsa plastik dapat meningkatkan hasil panen, memperpanjang musim tanam, mengurangi tekanan gulma, meningkatkan efisiensi penggunaan pupuk, menjaga kelembaban tanah, dan meningkatkan suhu tanah. Keterbatasan utama mulsa plastik polietilen mencakup limbah bahan mulsa setelah penggunaan. Saat ini, film mulsa yang dapat terurai secara hayati telah dipandang sebagai alternatif ekologis yang lebih berkelanjutan daripada mulsa plastik polietilen. Dalam upaya untuk mengatasi masalah limbah plastik pertanian yang parah dan terus berkembang, film yang dapat terbiodegradasi dibuat menggunakan limbah alami (kulit jagung) sebagai bahan penguat dan film yang dibuat digunakan untuk menghasilkan fim mulsa biodegradabel (bomulsa). Dalam penelitian ini telah dibuat film biomulsa berbahan dasar klobot jagung dan Linear Low Density Polyethylene (LLDPE) dengan menggunakan metode ekstrusi dan calandering. Biomulsa dibuat dengan variasi 5, 10, dan $15 \%$ (b/b) klobot jagung dan penambahan anti UV, tinuvin P sebesar $1 \%$. Film biomulsa selanjutnya dianalisis sifat mekanik, sifat termal, mikrostruktur, morfologi permukaan dan gugus fungsinya. Karakteristik mekanik film menunjukkan bahwa penambahan konsentrasi klobot jagung akan menurunkan sifat mekanik film. Konsentrasi klobot jagung 5\% memberikan hasil terbaik dengan nilai kekuatan tarik 14,52 $\mathrm{MPa}$, elongasi 358,10\% dan modulus elastisitas sebesar 0,37 GPa.

Kata kunci : biomulsa, calandering. klobot jagung, LLDPE

\section{PENDAHULUAN}

Teknologi mulsa adalah suatu sistem untuk memodifikasi suhu disekitar tanaman untuk mempercepat pertumbuhan dan meningkatkan kualitas produksi sebagai upaya peningkatan nilai ekonomis tanaman (Kasirajan dan Mathieu, 2012). Penggunaan mulsa plastik sudah menjadi standar umum dalam produksi tanaman hortikultura yang bernilai ekonomis tinggi, baik di negara-negara maju maupun di negara berkembang, termasuk Indonesia.
Plastik yang umum digunakan untuk teknologi mulsa berasal dari plastik sintetis seperti Linier Low Density Polyethylene (LLDPE) dan Polivinil Klorida (PVC) yang umumnya menimbulkan masalah lingkungan karena plastik tidak dapat terurai dalam lingkungan setelah selesai dengan penggunaannya.

Plastik LLDPE memiliki kemampuan yang baik dalam mempertahankan panas dan transmisi radiasi, tetapi plastik tersebut dapat terdegradasi akibat radiasi ultraviolet dari matahari secara terusmenerus. Berdasarkan hal tersebut diperlukan anti 
UV yang berfungsi untuk mengontrol proses degradasi pada mulsa pada saat penggunaan. Anti UV sangat penting karena pada plastik mulsa dapat menahan laju degradasi dari sinar ultraviolet matahari sehingga meningkatkan umur plastik mulsa, tidak mudah hancur dan terurai oleh alam. Kandungan UV yang seimbang pada kandungan mulsa membuat kekuatan plastik mulsa sangat baik, memiliki degradasi terkontrol sehingga petani dapat mempergunakan sampai beberapa kali pemakaian.

Seiring dengan isu global terkait suatu produk yang ramah lingkungan, maka teknologi biomulsa ini menjadi sangat menarik untuk dikembangkan. Pengembangan bahan plastik biodegradabel merupakan salah satu alternatif untuk memecahkan masalah ini. Salah satu serat alam yang belum termanfaatkan secara optimal dan memiliki potensi untuk dikembangkan menjadi bioplastik adalah kulit buah jagung atau klobot jagung yang sampai saat ini masih dianggap sebagai limbah. Klobot jagung di Indonesia cukup melimpah karena jagung merupakan komoditas yang mudah ditemukan di Indonesia. Menurut data Badan Pusat Statistik (BPS), produksi jagung pada tahun 2016 sebesar 23,19 juta ton. Klobot jagung merupakan salah satu bahan yang memiliki kandungan selulosa yang cukup tinggi sekitar $38,2 \%$, hemiselulosa $44,5 \%$, lignin $6,6 \%$, protein $1,9 \%$, abu $2,8 \%$ dan dari hasil panen buah jagung, bobot klobot jagung sekitar 38,4\%. (Yang et al., 2017).

Serat memiliki sifat mekanik yang baik dan sudah sering digunakan untuk pembuatan komposit dengan mencampurkannya pada berbagai polimer. Selulosa yang terkandung pada klobot jagung berperan sebagai penguat karena mempunyai struktur kristal. Sifat mekanis selulosa yang kuat menyebabkan selulosa berpotensi untuk dimanfaatkan sebagai penguat dalam komposit polimer (Zhijian et al., 2016).

Penelitian ini bertujuan untuk membuat film biomulsa klobot jagung-LLDPE dengan tiga varian komposisi klobot jagung yaitu 5\%, 10\%, dan $15 \%$, dalam pembuatannya digunakan bahan aditif yaitu Tinuvin $\mathrm{P}$ sebagai anti UV, Irganox sebagai antioksidan, gliserol sebagai plasticizer, dan asam oleat sebagai coupling agent. Selanjutnya film biomulsa dianalisis sifat mekanik, termal, struktur, morfologi dan sifat optiknya.

\section{BAHAN DAN METODE}

\section{Persiapan Bahan Baku}

Bahan yang digunakan dalam penelitian ini adalah klobot jagung manis yang diperoleh dari Pasar Induk Kemang Bogor. Klobot jagung lapisan ke 4 sampai dengan lapisan ke \pm 15 dibersihkan dan kemudian dicacah. Proses selanjutnya cacahan klobot jagung dikeringkan menggunakan oven sampai kadar air $10 \%$. Setelah pengeringan klobot jagung digiling kemudian diayak menggunakan saringan lolos 100 mesh $(149 \mu \mathrm{m})$. Serbuk klobot jagung dikarakterisasi komponen-komponennya (kadar air, protein kasar, lemak kasar, serat kasar, kadar abu dan karbohidrat) menggunakan metode yang berdasarkan pada SNI-01-2891-1992. Karakterisasi komponen serat dengan metode Van Soest (1991). Pengamatan gugus fungsi serta mikrostruktur juga dilakukan pada serbuk klobot jagung.

\section{Pencetakan Film Biomulsa}

Produksi film biomulsa dilakukan dengan tiga tahap pencampuran. Pertama adalah pencampuran serbuk klobot jagung, akuades dan giserol. Klobot jagung dan akuades dicampur terlebih dahulu sampai kadar air 25\%, setelah itu dicampur dengan $10 \%$ gliserol kemudian didiamkan selama 2 minggu. Kedua adalah pencampuran LLDPE, Asam Oleat (AO), Tinuvin P, dan Irganox. Asam oleat berfungsi sebagai plastisizer, Tinuvin $\mathrm{P}$ dapat memperlambat proses degradasi dan Irganox sebagai bahan antioksidan. LLDPE ditambah 0,2\% Irganox dengan pencampuran kering kemudian ditambahkan $1 \%$ Tinuvin P dan 2\% AO (Nurdayat et $a l ., 2004)$. Ketiga adalah pencampuran total dimana campuran pertama dan kedua dicampur dengan variasi $5,10,15$ (\%bb) campuran pertama. Selanjutanya $5 \%$ campuran disebut M5, $10 \%$ campuran disebut M10, 15\% campuran disebut M15. Pencampuran menggunakan alat ekstrusi pada suhu $180^{\circ} \mathrm{C}$ dengan kecepatan putar $30 \mathrm{rpm}$. Hasil ekstrusi kemudian dicetak dengan menggunakan alat cetak lembaran film (calandering) dengan lebar 15 $\mathrm{cm}$ dan target ketebalan $\pm 0,5 \mathrm{~mm}$.

\section{Karakterisasi Gugus Fungsional}

Pengamatan spektrum serapan infra merah pada biomulsa diamati dengan Fourier Transform Infrared (FTIR) spectrometer Bruker Tensor-37. Sampel sebanyak $2 \mathrm{mg}$ dibentuk pelet dengan penambahan Kbr $200 \mathrm{mg}$ (ketebalan $1 \mathrm{~mm}$ ). Pelet yang terbentuk dikenai sinar infra merah dengan rentang bilangan gelombang pada $400-4000 \mathrm{~cm}^{-1}, 32$ scan dan resolusi $4 \mathrm{~cm}^{-1}$. Analisis FTIR dilakukan untuk mengetahui keberadaan gugus fungsional serbuk klobot jagung serta film biomulsa M5, M10 dan M15.

\section{Karakterisasi Termal}

Sifat termal serbuk klobot jagung berukuran 100 mesh, film biomulsa M5, M10 dan M15 dikarakterisasi menggunakan alat Differential Scanning Calorimetry (DSC), Perkin-Elmer Co Norwalk yang dapat mengukur secara kuantitatif perubahan entalpi yang timbul sebagai fungsi dari suhu dan waktu. Pengujian dilakukan dengan kondisi sampel ditahan pada suhu $30^{\circ} \mathrm{C}$ selama 5 menit dan kemudian dilakukan pemanasan sampai $200^{\circ} \mathrm{C}$ dengan kecepatan $5^{\circ} \mathrm{C} /$ menit. 


\section{Karakterisasi Mikrostuktur}

Mikrostruktur serbuk klobot jagung dan film biomulsa kode sampel M5, M10 dan M15 diamati dengan X-ray diffractometer (XRD)-700 Shimadzu pada posisi statis menggunakan sumber radiasi $\mathrm{Cu}$ $\mathrm{K} \alpha(\lambda=1,5418 \AA)$ dengan kondisi operasi pada 40 $\mathrm{kV}, 30 \mathrm{~mA}$, sudut $2 \theta=10-80^{\circ}$ dan kecepatan scan $2 \%$ menit.

\section{Karakterisasi Sifat Mekanik}

Pengujian mekanik dilakukan dengan menggunakan Universal Testing Machine (UTM) dengan merk Shimadzu tipe AGS-10 Kg. Uji tarik dilakukan dua arah dan disesuaikan dengan standar ASTM D638, dengan ketebalan $\pm 0,5 \mathrm{~mm}$ (Wu, 2014). Uji tarik ASTM D638 ini merupakan standar yang dirancang untuk mengetahui sifat tarik untuk kontrol dan spesifikasi dari bahan plastik. Setiap sampel diambil lima spesimen untuk pengujian sifat mekanik. Proses penarikan sampel dilakukan dengan dengan kecepatan $5 \mathrm{~mm} /$ menit pada suhu $22,4^{\circ} \mathrm{C}$ dan kelembaban relatif $58 \%$, penarikan dilakukan hingga sampel mengalami perpatahan. Hasil dari pengujian tarik ini adalah kurva teganganregangan yang menunjukkan ketahanan benda atau sampel terhadap pemberian beban tarik dan nilai persentase pertambahan panjang saat terjadi perpatahan (elongation at break) bahan. Sampel yang diuji adalah film biomulsa M5, M10 dan M15.

\section{Karakterisasi Morfologi Permukaan}

Morfologi biomulsa diamati menggunakan Scanning Electron Microscopy (SEM) merk JEOL JSM-6510 LA dengan tegangan akselerasi elektron $20 \mathrm{kV}$ dan perbesaran 100 kali dan 1000 kali. Sampel yang diuji SEM adalah film biomulsa M5, M10 dan M15.

\section{Karakterisasi Sifat Optik}

Pengujian UV-Vis bertujuan untuk mengetahui karakteristik absorbansi dan pengaruh penambahan tinuvin $\mathrm{P}$ pada film biomulsa. Pengujian dilakukan dengan perangkat Ocean Optik UV-Vis serial USB4000FL. Pengukuran dilakukan pada rentang $200-800 \mathrm{~nm}$, dimana rentang UV pada 200-400 nm dan cahaya tampak pada 400-800 nm.

\section{HASIL DAN PEMBAHASAN}

Analisis Proksimat dan Komponen Serat

Analisis proksimat dilakukan untuk mengetahui komposisi dari serbuk klobot jagung. Hasil uji disajikan pada Tabel 1. Berdasarkan data tersebut serbuk klobot jagung memiliki kandungan kadar lemak dan protein yang rendah, artinya tidak baik untuk dijadikan pakan ternak (Bunyamin et al., 2013).

Klobot jagung memiliki kadar abu yang kecil yakni sebesar 5,14\%. Berdasarkan penelitian oleh Liu et al. (2010), kadar abu dalam ukuran 14-50 $\mu \mathrm{m}$ dapat meningkatkan kuat tarik komposit dengan matriks HDPE. Serat kasar dan karbohidrat memiliki konsentrasi tertinggi yakni berkisar di $25,48 \%$ dan $57,90 \%$. Penambahan serat alami berfungsi untuk mensubstitusi penggunaan polimer sintetis dan sudah sering digunakan untuk pembuatan komposit dengan mencampurkannya pada berbagai polimer (Zhijian et al., 2016).

Tabel 1. Hasil uji proksimat serbuk klobot jagung 100 mesh

\begin{tabular}{lc}
\hline \multicolumn{1}{c}{$\begin{array}{c}\text { Parameter Uji } \\
(\% \mathbf{b b})\end{array}$} & Nilai \\
\hline Kadar air & $9,71 \pm 0,02$ \\
Kadar abu & $5,14 \pm 0,04$ \\
Kadar protein kasar & $5,15 \pm 0,01$ \\
Kadar serat kasar & $25,48 \pm 0,30$ \\
Selulosa & $23,48 \pm 0,26$ \\
Hemiselulosa & $32,82 \pm 0,41$ \\
Lignin & $9,23 \pm 0,02$ \\
Kadar lemak kasar & $1,28 \pm 0,03$ \\
Kadar karbohidrat* & $53,24 \pm 0,34$ \\
\hline${ }^{* B y}$ Difference
\end{tabular}

\section{Mulsa Klobot Jagung}

Mulsa dicetak dengan menggunakan alat ekstrusi calandering, yang menghasilkan plastik panjang dengan ketebalan $\pm 0,5 \mathrm{~mm}$ dan lebar $15 \mathrm{~cm}$. Foto hasil pencetakan dapat dilihat pada Gambar 1 . Dari Gambar 1 terlihat bahwa warna mulsa semakin gelap dengan semakin besarnya konsentrasi klobot jagung.

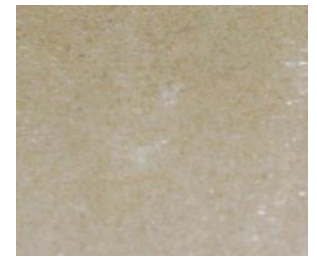

(a)

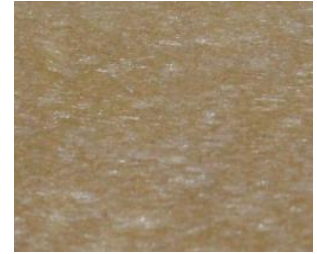

(b)

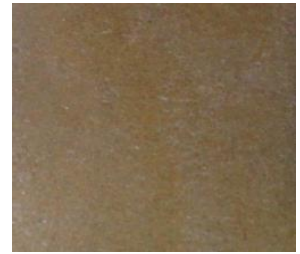

(c)

Gambar 1. Mulsa (a) M5, (b) M10 dan (c) M15 
Penyebaran secara merata material-material matriks dalam suatu komposit merupakan hal yang sangat penting. Penyebaran material-material tersebut mempengaruhi sifak mekanik dalam komposit tersebut (Wu, 2014). Analisis morfologi dengan SEM dilakukan untuk mengamati morfologi film biomulsa yang dihasilkan. Hasil SEM berukuran 100 mesh atau $149 \mu \mathrm{m}$ ditunjukkan pada Gambar 2 bahwa film biomulsa memiliki pori-pori atau ruang kosong, ini memungkinkan untuk disisipi oleh LLDPE sehingga mempermudah pencampuran.

Gliserol dan asam oleat merupakan cairan yang memiliki titik leleh dibawah suhu ruang yakni $18^{\circ} \mathrm{C}$ dan $14^{\circ} \mathrm{C}$ (Pubchem, 2017). Tinuvin $\mathrm{P}$ dan Irganox berwujud kristal yang memiliki titik leleh $132^{\circ} \mathrm{C}$ dan $55^{\circ} \mathrm{C}$ (Ciba, 1998). Titik leleh LLDPE berkisar di $120^{\circ} \mathrm{C}-160^{\circ} \mathrm{C}$ sementara klobot jagung titik leleh sebesar $290^{\circ} \mathrm{C}$ (Ciba, 2009). Pencampuran bahan-bahan penyusun mulsa menggunakan single screw extruder dengan suhu $180^{\circ} \mathrm{C}$, dimana suhu ini lebih tinggi dibandingkan dengan titik leleh dari bahan-bahan penyusun mulsa kecuali klobot jagung yang memiliki suhu degradasi $196,21^{\circ} \mathrm{C}$. Selain pengaruh suhu juga terdapat pengaruh mekanik dari perputaran sekrup hal ini membantu untuk materialmaterial tersebut lebih mudah meleleh. Berdasarkan titik leleh tersebut gumpalan pada permukaan mulsa sebagian besar merupakan serbuk klobot jagung dan sebagian kecil tinuvin P. Adanya gumpalan di permukaan mulsa mengindikasikan kurang meratanya distribusi serbuk klobot jagung dan bahan aditif lainya di dalam film biomulsa. Hal ini diakibatkan oleh sifat yang berbeda antara LLDPE dan klobot jagung. Klobot jagung bersifat hidrofilik dan LLDPE bersifat hidropobik. Selain itu perbedaan skema ikatan hidrogen antar klobot jagung dan LLDPE membuat ikatan antar permukaan tidak maksimal.

\section{Analisis Gugus Fungsi Klobot Jagung dan Film Biomulsa}

Hasil analisis FTIR disajikan pada Gambar 3. Berdasarkan spektrum FTIR, ikatan O-H regang, hidroksil bebas pada bilangan gelombang $3742 \mathrm{~cm}^{-1}$ teridentifikasi dalam gugus fungsi alkohol, air, dan fenol. Ikatan O-H regang, ikatan $\mathrm{H}$ - pada $3416 \mathrm{~cm}^{-1}$ terindentifikasi dalam gugus fungsi yang sama dengan sebelumnya. Puncak pada bilangan gelombang $2921 \mathrm{~cm}^{-1}$ merupakan ikatan $\mathrm{C}-\mathrm{H}$ regang yang teridentifikasi dalam gugus fungsi alkana dan asam karboksilat. Ikatan $\mathrm{C}-\mathrm{H}$ regang pada bilangan gelombang $2361 \mathrm{~cm}^{-1}$ teridentifikasi dalam gugus fungsi metil dan alifatik jenuh.

Ikatan $\mathrm{C}=\mathrm{O}$ regang pada bilangan gelombang $1827 \mathrm{~cm}^{-1}$ teridentifikasi dalam gugus fungsi ester dan alifatik jenuh (lemak), sementara pada bilangan gelombang $1735 \mathrm{~cm}^{-1}$ dalam gugus fungsi ester dan alifatik jenuh (protein) sesuai dengan penelitian Alfiani et al. (2014). Ikatan N-H tekuk pada bilangan gelombang $1649 \mathrm{~cm}^{-1}$ teridentifikasi gugus fungsi amina (amilase). Ikatan $\mathrm{C}=\mathrm{C}$ regang pada bilangan gelombang $1517 \mathrm{~cm}^{-1}$ teridentifikasi gugus fungsi alkena (lignin). Ikatan C-C vibrasi pada $1252 \mathrm{~cm}^{-1}$ teridentifikasi gugus fungsi alkil dan C-O regang pada $1040 \mathrm{~cm}^{-1}$ dalam gugus fungsi alkohol (selulosa, hemiselulosa, lignin), asam karboksil, ester, dan eter. Hasil uji proksimat, serat, dan analisis kurva FTIR memungkinkan untuk klobot jagung dijadikan sebagai bahan substitusi pembuatan bioplastik, sehingga dapat mengurangi penggunaan plastik secara penuh.

Hasil Spektrum FTIR dapat dilihat pada Gambar 4. Spektrum tersebut menunjukkan tidak terdapat perbedaan yang signifikan antara mulsa M5, M10 dan M15, dimana terdapat puncak lemah dan kuat. Spektrum vibrasi dari suatu molekul memiliki keunikan tersendiri yang bisa menjadi karakteristik dari molekul tersebut (Coates, 2000). Inframerah merupakan gelombang yang dapat mendeteksi spektrum vibrasi dari molekul, sehingga pada spektrum inframerah dapat digunakan untuk melihat karakteristik ikatan/gugus fungsi suatu material. Spektrum FTIR film biomulsa jika dibandingkan dengan hasil-hasil penelitian sebelumnya yang membahas tentang material utama penyusun film biomulsa, menunjukkan terdapat beberapa kesamaan puncak yang terbentuk. Spektrum FTIR LLDPE hasil penelitian Konoz et al. (2011) memiliki kesamaan pola pada puncak $714 \mathrm{~cm}^{-1}, 770 \mathrm{~cm}^{-1}$, $1374 \mathrm{~cm}^{-1}$ dan $1639 \mathrm{~cm}^{-1}$.

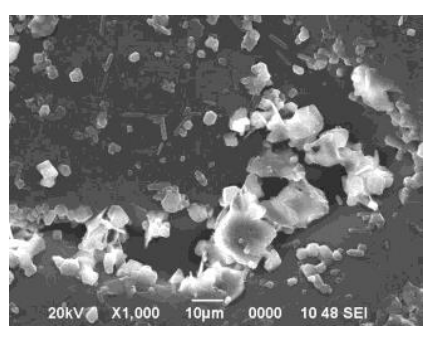

(a)

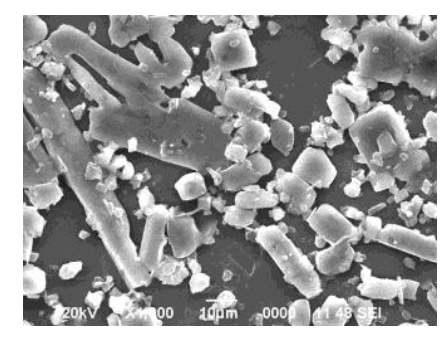

(b)

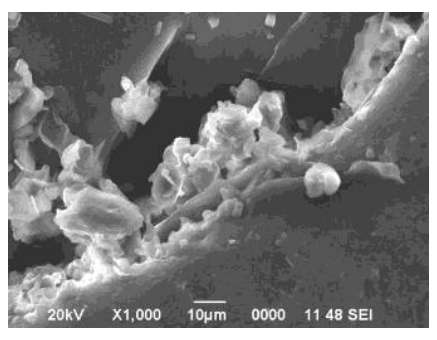

(c)

Gambar 2. SEM film biomulsa (a) M5 (b) M10 (c) M15; perbesaran 1000 kali 


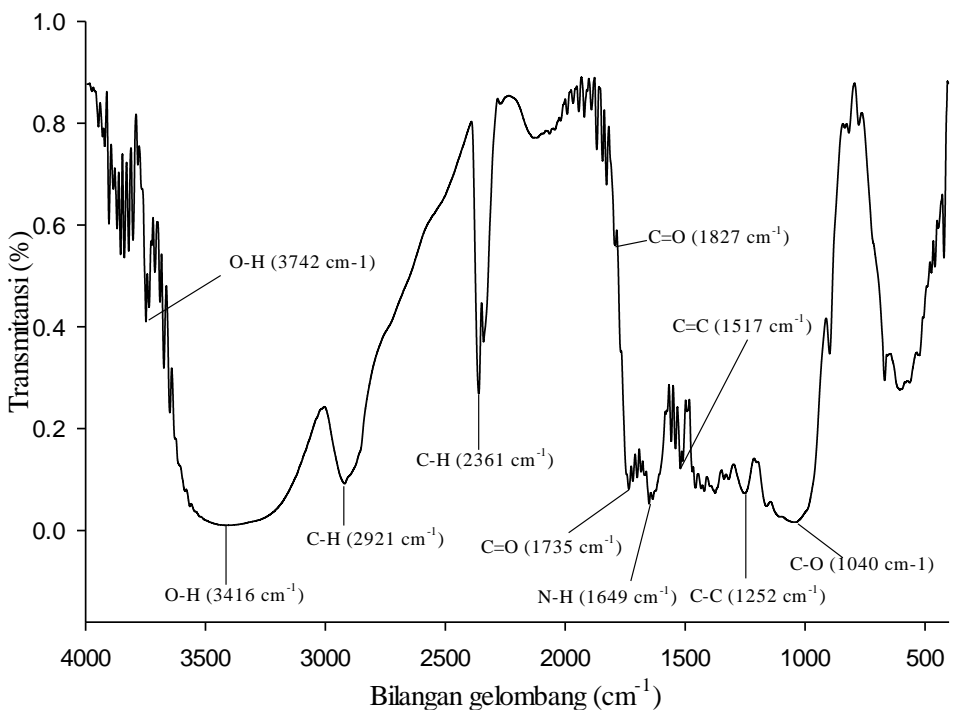

Gambar 3. Grafik FTIR serbuk klobot jagung berukuran 100 mesh

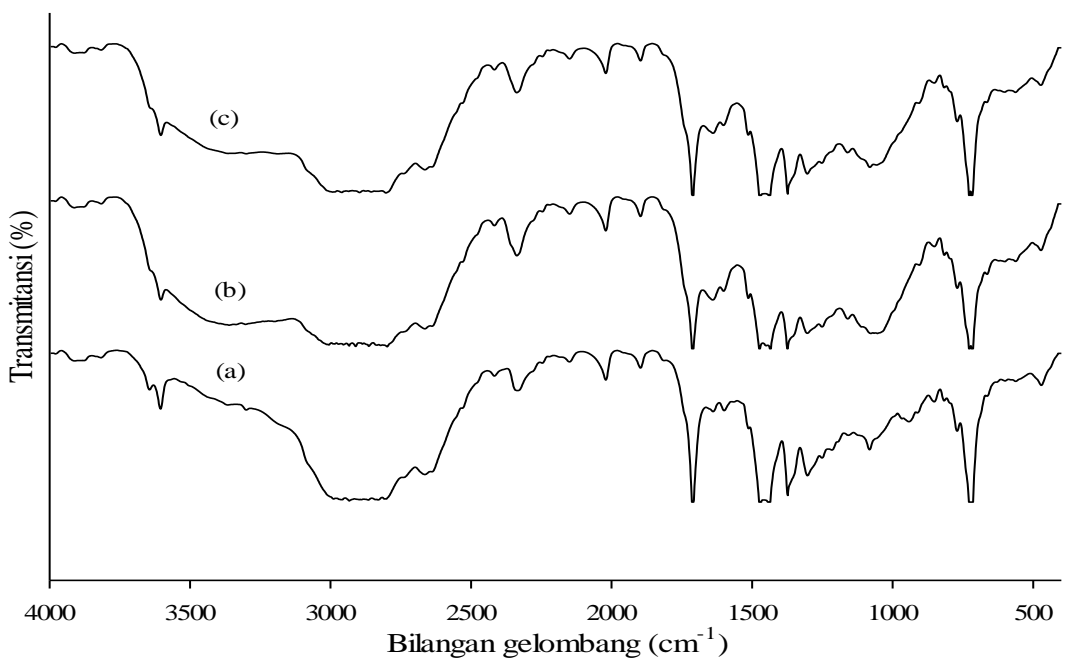

Gambar 4. Spektrum FTIR klobot jagung dan mulsa dengan variasi (a) M5, (b) M10 dan (c) M15

\section{Analisis Termal Mulsa}

Analisis termal bertujuan untuk mengetahui karakteristik termal dan kristalisasi dari serbuk klobot jagung dan mulsa klobot jagung. Salah satu karakteristik termal yakni suhu transisi gelas, dimana terjadi perubahan sifat bahan yang semula padat seperti gelas menjadi lunak seperti karet. Suhu transisi gelas ditentukan melalui interpolasi saat terjadi reaksi endotermis pertama, dimana bahan mulai menyerap panas hingga terjadi pelepasan kalor ke lingkungan.

Karakteristik puncak endotermik serbuk klobot jagung berukuran 100 mesh ditunjukkan pada Gambar 5. Kurva endotermik tersebut memiliki rentang dari $33^{\circ} \mathrm{C}$ sampai $130^{\circ} \mathrm{C}$, dengan puncak di $70^{\circ} \mathrm{C}$, dalam selang tersebut terjadi perubahan fasa kristal menjadi lebih amorf dan dari padat menjadi lebih elastic. Karakteristik termal film biomulsa ditunjukan oleh Gambar 6, dimana nilai Tg dari ketiga variasi tersebut cenderung meningkat dengan peningkatan konsentrasi klobot jagung. Nilai Tgbiomulsa berkisar diantara $116-119^{\circ} \mathrm{C}$, peningkatan ini diakibatkan oleh penurunan ruang kosong dalam pergerakan molekul pada mulsa (Wu, 2014).

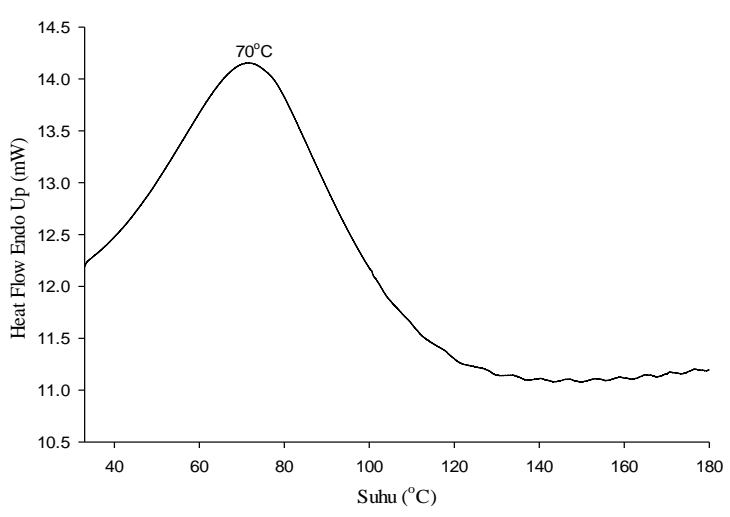

Gambar 5. Grafik DSC serbuk klobot berukuran 100 mesh 


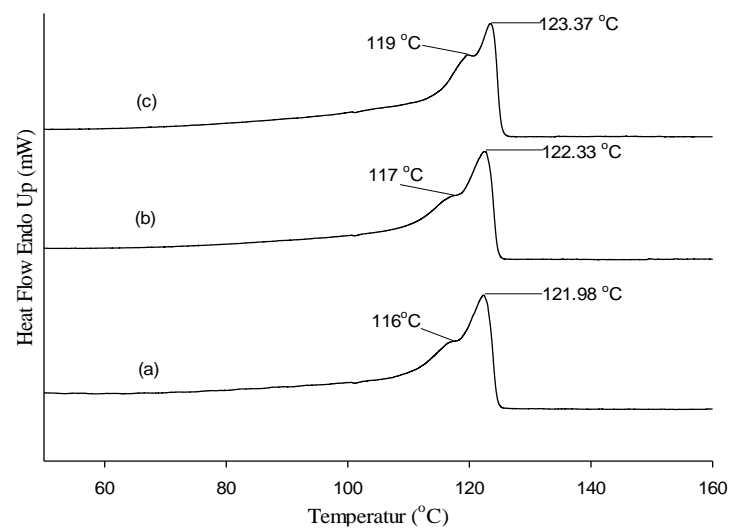

Gambar 6. Grafik DSC film biomulsa (a) M5, (b) M10 (c) M15

Nilai ini lebih besar dibandingkan suhu lingkungan, dimana plastik dikatakan dapat berfungsi dengan baik jika memiliki suhu Tg diatas suhu lingkunganya (Stevens et al., 2007). Terdapat dua puncak endoterm berdekatan dalam kurva DSC yang menunjukan adanya dua morfologi kristal yang berbeda pada mulsa yang serupa dengan penelitian Run et al. (2009). Adanya dua puncak juga menunjukkan ketidakhomogenan pencampuran bahan-bahan mulsa seperti ditunjukkan pada analisis SEM. Entalpi pada endoterm atau energi yang diperlukan untuk terjadinya perubahan fasa mengalami peningkatan, dengan peningkatan konsentrasi klobot pada film biomulsa. Besar nilai entalpi untuk film biomulsa M5, M10 dan M15 berturut-turut adalah $69,096 \mathrm{~J} / \mathrm{g}, 75,259 \mathrm{~J} / \mathrm{g}$, dan $83,975 \mathrm{~J} / \mathrm{g}$. Nilai entalpi dapat menjadi indikator kristalinitas suatu material, dimana semakin besar nilai enatalpinya maka semakin tinggi kristalinitasnya (Wu, 2014; Run et al,. 2009).

\section{Analisis Struktur Biomulsa}

Grafik XRD pada Gambar 7 menunjukkan pola yang serupa dengan hasil DSC. Dimana klobot jagung memiliki satu puncak, sementara mulsa memiliki dua puncak dominan. Klobot jagung memiliki satu puncak dominan di $2 \theta=22,47^{\circ}$. Mulsa memiliki dua puncak dominan dimana untuk

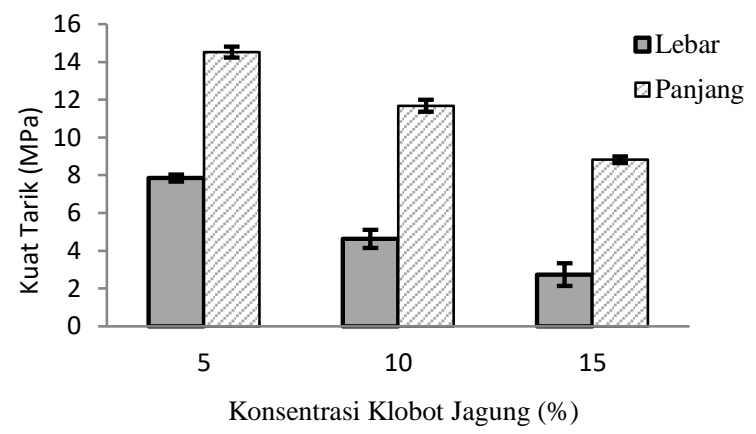

(a) film biomulsa M5 memiliki dua puncak tertinggi di $2 \theta=21,637^{\circ}$ dan $2 \theta=23,938^{\circ}$. Film biomulsa M10 memiliki dua puncak tertinggi di $2 \theta=21,777^{\circ}$ dan $2 \theta=24,063^{\circ}$. Film biomulsa M15 memiliki dua puncak tertinggi di $2 \theta=21,721^{\circ}$ dan $2 \theta=24,027^{\circ}$. Berdasarkan literatur (Yan Jie dan Wei Dong, 2007), LLDPE murni memiliki dua puncak dominan antara lain $2 \theta=21,7^{\circ}$ dan $24,2^{\circ}$. Berdasarkan hal ini, dua puncak pada film biomulsa merupakan puncak kristalin dari matriks LLDPE. Karakteristik dari puncak-puncak mulsapun tidak berbeda jauh, ini dikarenakan klobot jagung merupakan material alami yang bersifar amorf.

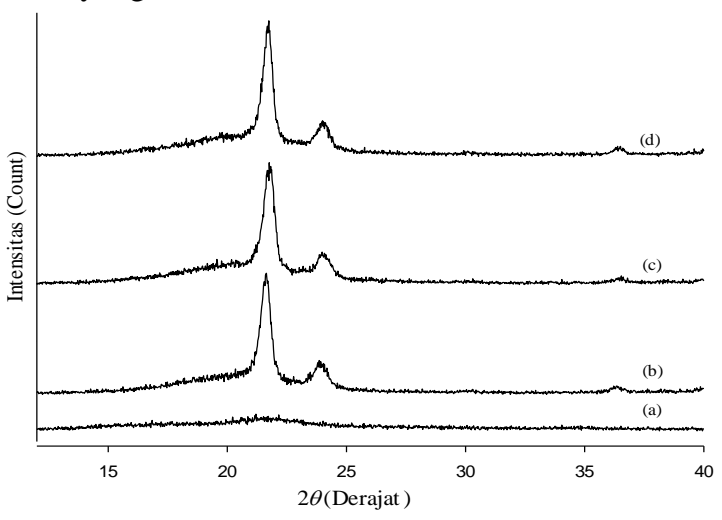

Gambar 7. Grafik XRD (a) Klobot jagung 100 mesh (b) Film biomulsa M5 (c) Film biomulsa M10 (d) Film biomulsa M15

\section{Analisis Sifat Mekanik Film Biomulsa}

Hasil uji dapat dilihat pada Gambar 8 dan 9. Dari hasil uji tarik didapatkan kekuatan tarik, modulus elastisitas, dan elongation at break. Untuk sisi panjang, semakin meningkatnya konsentrasi klobot jagung membuat kekuatan tarik dari mulsa mengecil. Hal ini diakibatkan oleh pengaruh interaksi antar LLDPE dan klobot tidak sekuat LLDPE murni itu sendiri sesuai dengan Wu (2014). Hasil tersebut juga terlihat pada kekuatan tarik dari sisi lebar.

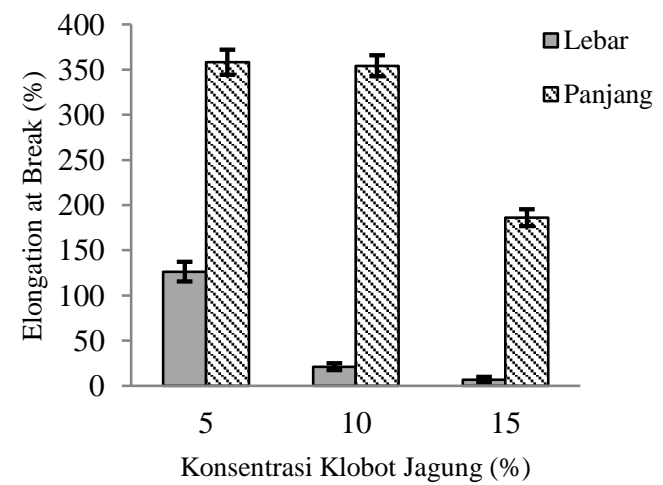

(b)

Gambar 8. (a) Kekuatan tarik dan (b) Elongation at Break 


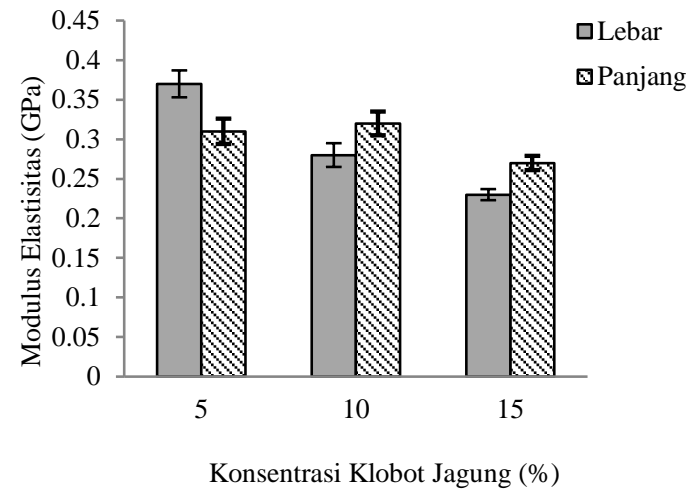

Gambar 9. Modulus elastisitas mulsa

Besar kuat tarik untuk LLDPE murni berdasarkan data yang dikeluarkan oleh Prospector ${ }^{\circledR}$ memiliki rentang 6,96-31,37 $\mathrm{MPa}$. Rentang ini masih sesuai dengan kuat tarik untuk sisi panjang dimana memiliki rentang 8,82-14,52 MPa. Kuat tarik sisi lebar hanya film biomulsa M5 yang masih masuk dalam rentang LLDPE murni, yakni 7,85 $\mathrm{MPa}$, sementara film biomulsa M10 dan M15 besarnya dibawah rentang tersebut.

Modulus elastisitas merupakan kemampuan bahan melawan perubahan bentuk atau deformasi permanen akibat pembebanan. Berbeda dengan hasil kuat tarik, nilai modulus elastisitas untuk panjang terbesar pada mulsa M10 sebesar 0,32 GPa, sedangkan untuk lebar pada mulsa M5 sebesar 0,37 GPa. Jika batas ini dilewati maka mulsa tersebut akan mengalami kerusakan (Oroh et al., 2013). Besar modulus elastisitas tersebut tidak berbeda jauh dengan LLDPE murni sesuai data Prospector ${ }^{\circledR}$ yakni pada rentang 0,24-0,42 GPa.

Elongation at break merupakan kemampuan material dalam menahan beban sehingga material tersebut tidak putus, walaupun terjadi kerusakan permanen. Berdasarkan Gambar 9 terlihat perbedaan yang sangat signifikan antara sisi panjang dan sisi lebar. Dimana sisi panjang memiliki kemampuan elastisitas lebih besar dibandingkan sisi lebar seperti pada kuat tarik. Hal ini diakibatkan arah pencetakan mulsa searah dengan sisi panjang, sehingga seratserat lebih dominan mengarah ke sisi panjang. Besar elongation at break LLDPE murni berdasarkan data Prospector ${ }^{\circledR}$ memiliki rentang dari 47\%-1000\%. Sama seperti kuat tarik, strain at break sisi panjang masuk dalam rentang tersebut, sementara sisi lebar hanya mulsa M5 yang masih masuk dalam rentang LLDPE murni.

Bahan pemlastis (gliserol) ditambahkan untuk mengurangi kekakuan dari polimer dan meningkatkan fleksibilitas polimer tersebut. Penambahan pemlastis dalam jumlah kecil agar tidak melemahkan plastik yang dihasilkan (Zulferiyenni et al., 2014). Pencampuran pertama antara gliserol dan klobot menyebabkan terjadi interaksi antara gliserol dan klobot sehingga sifat mekaniknya lebih baik. Begitu pula penambahan asam oleat, bertujuan untuk menjadi perekat antara campuran satu dan LLDPE yang nantinya dapat berpengaruh ke sifat mekaniknya.

Pemlastis inilah yang membuat nilai modulus elastisitas antara lebar dan panjang tidak berbeda jauh, bahkan pada film biomulsa M5 nilai modulus elastisitas lebih besar pada sisi lebar. Interaksi antara glilserol dan klobot, serta fungsi asam oleat yang masih belum maksimal mengakibatkan penurunan sifat mekanik.Ini terbukti dengan terjadinya penurunan nilai kekuatan tarik dan strain at break dengan peningkatan konsentrasi klobot jagung. Selain itu pada analisis SEM menunjukan ketidakhomogenan mulsa yang artinya material seperti gliserol dan asam oleat belum berfungsi maksimal.

\section{Analisis Sifat Optik Film Biomulsa}

Mulsa memiliki warna jingga hingga kecoklatan, warna komplementer dari jingga adalah biru kehijauan dengan rentang panjang gelombang 480-490 nm (Shameli et al., 2010). Warna komplementer merupakan warna yang terlihat ketika disinari cahaya tampak, berbeda dengan warna yang diserap. Berdasarkan Gambar 10 puncak absorbsi untuk film biomulsa M5 dan M10 terletak di panjang gelombang $480 \mathrm{~nm}$, untuk film biomulsa M15 di panjang gelombang $481 \mathrm{~nm}$. Hal ini sesuai dengan warna dari mulsa, dimana warna yang diserap disekitar rentang 480-490 $\mathrm{nm}$. Dalam rentang UV semakin besar konsentrasi klobot jagung maka semakin kecil daya serapnya terhadap UV, sementara pada pemaparan cahaya tampak terjadi peningkatan drastis pada film biomulsa M15. Hal ini dikarenakan warna pada film biomulsa M15 lebih gelap dibandingkan yang lainya dan film biomulsa M10 lebih gelap dibandingkan film biomulsa M5 ketika memasuki rentang cahaya tampak. Selain pengaruh warna terdapat juga pengaruh dari karbohidrat yang terkandung dalam klobot jagung (Kaijanen et al., 2015).

Karbohidrat terbagi atas dua kelompok yakni aldosa yang memiliki gugus aldehid dan ketosa yang memiliki gugus keton. Ikatan rangkap dimiliki oleh karbohidrat dari aldehid dan keton, sementara LLDPE tidak memiliki ikatan rangkap akibat dari reaksi adisi saat pembentukannya. Transisi elektron yang terjadi akibat radiasi UV-Vis pada karbohidrat adalah $\pi-\pi^{*}$ dan $n-\pi^{*}$ dimana transisi ini memerlukan energi yang kecil dan panjang gelombang yang besar. 


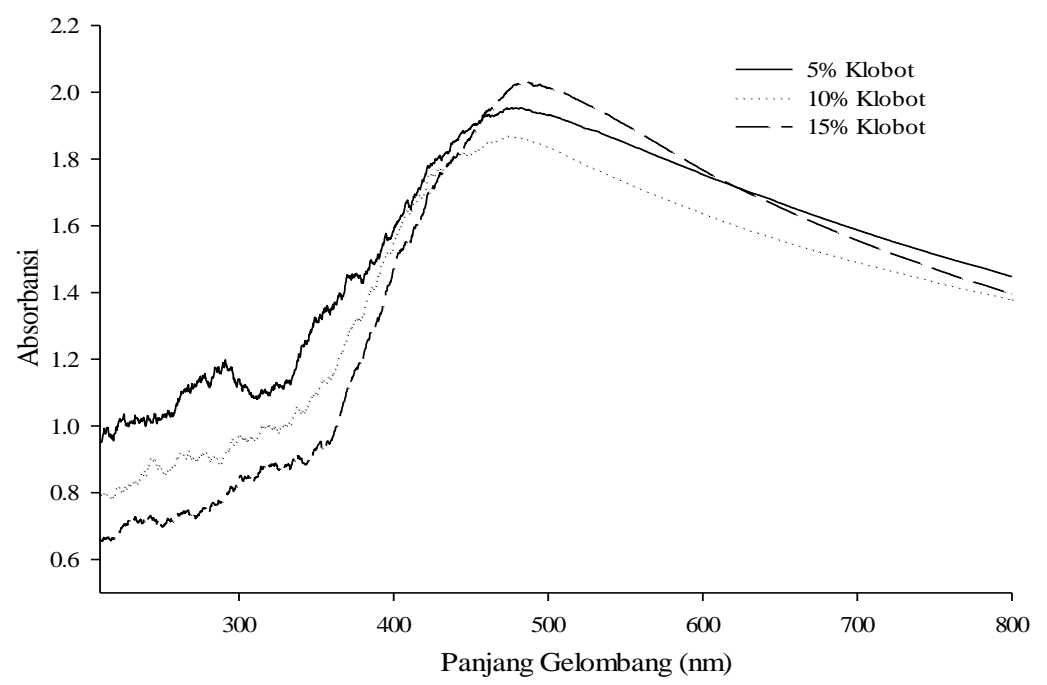

Gambar 10. Spektrum absorbansi UV-Vis mulsa

Semakin banyak ikatan rangkap yang terkonjugasi maka semakin kecil celah energinya (Vojta, 2017). Transisi ini sesuai dengan spektrum yang diperlihatkan pada Gambar 10 . Tinuvin P merupakan Ultraviolet light absorber (UVA) dari kelas hydroxyphenol benzotriazole, yang penggunaanya dengan mencampurkan pada berbagai jenis polimer. Tinuvin memiliki kemampuan menyerap maksimum sinar ultraviolet pada rentang 300-400 $\mathrm{nm}$ dan stabil terhadap cahaya selama penyinaran (Ciba, 1998). Gambar 11 menunjukkan struktur kimia dari Tinuvin P, dimana terdapat ikatan rangkap yang memilki transisi $\pi-\pi^{*}$ dan $n-\pi^{*}$. Dari data yang diperoleh film biomulsa M5 memiliki daya serap UV lebih baik dibandingkan film biomulsa M10 dan M15.

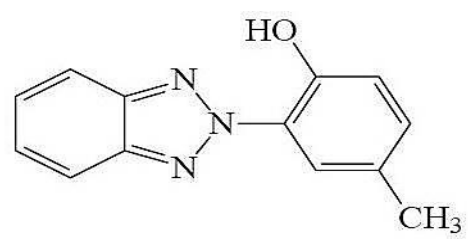

Gambar 11. Struktur kimia Tinuvin P (Ciba, 1998)

Puncak pada rentang UV hanya terdeteksi pada konsentrasi $5 \%$ pada panjang gelombang 290 nm. Ini menunjukkan adanya penyerapan radiasi UV yang ditimbulkan oleh tinuvin P. Pada film biomulsa M10 dan M15 tidak ada puncak yang dominan, dikarenakan pengaruh penambahan klobot jagung. Klobot jagung merupakan material organik yang memiliki gugus rangkap $\mathrm{C}$ dan $\mathrm{O}$ dimana memungkinkan terjadi transisi elektron $\pi-\pi^{*}$ dan n$\pi^{*}$. Transisi elektron $n-\pi^{*}$ memiliki energi lebih rendah dibandingkan $\pi-\pi^{*}$. Berbeda dengan LLDPE yang banyak memiliki ikatan $\mathrm{C}$ tunggal, memungkinkan terjadinya transisi dengan energi yang lebih besar yakni transisi $\sigma-\sigma^{*}$. Penambahan klobot jagung mengakibatkan bergesernya puncak pada rentang UV sehingga tidak muncul puncak dominan untuk film biomulsa M10 dan M15 akibat pengaruh transisi elektron $n-\pi *$.

\section{KESIMPULAN DAN SARAN}

\section{Kesimpulan}

Berdasarkan hasil proksimat, serat dan FTIR klobot jagung berpotensi sebagai penguatfilm mulsa. Permukaan film biomulsa tidak homogen dan terdapat gumpalan-gumpalan yang merupakan klobot dan tinuvin P. Analisis termal menunjukkan mulsa dapat berfungsi baik secara termal dan energi entalpinya meningkat dengan peningkatan klobot jagung, sesuai dengan analisis XRD. Sifat mekanik cenderung menurun dengan penambahan konsentrasi klobot jagung, dimana ikatan gliserol dan klobot serta fungsi asam oleat optimal. Film biomulsa menyerap maksimum cahaya pada panjang gelombang $480 \mathrm{~nm}$.

\section{Saran}

Film biomulsa dalam penelitian ini menunjukkan kemampuan absorpsi optik yang baik dan selanjutnya pembuatan film dapat dikembangkan dengan memberikan warna pada biomulsa sehingga diharapkan dapat meningkatkan kemampuan biomulsa terutama untuk mengontrol suhu pada tanaman.

\section{DAFTAR PUSTAKA}

[Ciba] Ciba Specialty Chemical.1998.Tinuvin P Benzotriazole UV Absorber.http://www .polivinilplasti k.com/urunler/tinp.pdf.[20 Januari 2017].

[Ciba] Ciba Specialty Chemical. 2009. Irganox 1076 [diunduh tanggal 20 Januari 2017]. 
Tersedia pada: http://www.shanghaigu anan.com/pic/20149161135665 5.pdf

[Pubchem]. 2017. Oleic Acid.https://pubchem.ncbi. nlm.nih.gov/compound loleic acid\#section=Top. [20 Januari 2017].

Alfiani S, Lilig T, dan Malikhatun N. 2014. Analsis kadar asam lemak bebas dalam minyak hasil penggorengan berulang dengan metode tirasi asam basa dan spektrototometer fourier transformation infra red (FTIR). Journal Pharma Science. 1(1):7-13.

Brodhagen M, Peyron M, Miles C, Inglis DA. 2015. Biodegradable plastic agricultural mulches and key features of microbial degradation. Appllied Microbiol Biotechnol.99(3): 10391056, doi 10.1007/s00253-014-6267-5.

Bunyamin Z, Roy E, dan Andayani. 2013. Pemanfaatan limbah jagung untuk industri pakan ternak. Seminar Nasional Inovasi Teknologi Pertanian.153-166.

Coates J. 2000. Interpretation of Infrared Spectra, A Practical Approach. Encyclopedia of Analytical Chemistry, R.A. Meyers (Ed.):10815-10837.

Kaijanen L, Maaret P, Suvi P, Eeva J, Satu-Pia R. 2015. Ultraviolet detection of monosaccharides: multiple wavelength strategy to evaluate result after capillary zone electrophoretic separation. International Journal Electrochem. Science. 10:2950-2961.

Kasirajan S dan Ngouajio M. 2012. Polyethylene and biodegradable mulches for agricultural application: a review. Agron Sustain Dev. 32:501-529, doi 10.1007/s13593-011-00683.

Konoz E, Amir HMS, Feazbakhs A, Zamani E. 2012. Characterization and quantification of the cross-linking of linear low density polyethylene with silane grafting by Fourier transform infrared (FTIR) spectroscopy. Journal Iranian Chemical Res. 5(1):31-38.

Liu Min, Huang Z, dan Yang Y. 2010. Analysis of biodegradable of three biodegradable mulching films. Springher. Journal Polymers Environment. 18: 148-154.

Nurdayat S, Kemala T, Sudirman, Karo-Karo A. 2004. Pengaruh penambahan anti UV tinuvin 783 terhadap karakteristik polivinil klorida. Sains Materi Indonesia. 6(1): 3239.

Oroh J, Sapupu FP, dan Lumitang R. 2013. Analisi sifat mekanik material komposit dari serat sabut kelapa. e-journal Universitas Sam Ratulangi.1(1):1-10.
Run M, Song H, Wang S, Libin B, Yinghua J. 2009. Crystal morphology, melting behaviors and isothermal crystallization kinetics of SCF/PTT composite. Polym Composite:87-94.

Shameli K, Mansoor BA, dan Wan MZWY. 2010. Silver/poly (latic acid) nanocomposite: preparation, characterization and antibacterial activity. International Journal Nanomedicine. 5(1):573-579.

Stevens RJ, Leonid VZ, dan Pamela MN. 2007. Effects of temperature and disorder on thermal boundary conductance at solidsolid interfaces: Nonequilibrium molecular dynamics simulations. International Journal Heat and Mass Transfer. 50:39773989.

Van Soest PJ, Robertson JB, dan Lewis BA. 1991. Methods for dietary fiber, neutral detergent fiber, and non starch polysaccharides in relation to animal nutrition. Journal Dairy Science. 74: 3583-3597.

Vojta D, Eva MK, dan Jens SL. 2017. Electronic states of myricetin. UV-Vis polarization spectroscopy and quantum chemical calculation. Spectrochimica Acta part A: Molecular and Biomolecular Spectroscopy. 173:182-187.

Wu CS. 2014. Preparation and characterization of polyhydroxyalkanoate bioplastic-based green renewable composite from rice husk. Journal Polym Environ. 22:384-392, doi 10.1007/s10924-014-0662-y.

Yan JW dan Yan WD. 2007. Investigation on chain structure of LLDPE obtained by ethylene in-situ copolymerization with DSC and XRD. Chinese Science Bulletin. 52(6): 736742.

Yang X, Han F, Xu C, Jiang S, Huang L, Liu L. 2017. Effects of preparation methods on the morphology and properties of nanocellulose (NC) extracted from corn husk. Industrial Crops and Product. 109: 241-247. doi:10.1016/j.indcrop.2017.08.032.

Zhijian T, Yongjian Y, Hongying W, Wanlai Z, Yuanru Y, Chaoyun W. 2016. Physical and degradable properties of mulching film prepared from natural fibers and biodegradable polymers. Appllied Science. 6:147-152.

Zulferiyenni, Marmiza, dan Erli NS. 2014. Pengaruh konsentrasi gliserol dan tapioka terhadap karakteristik biodegradable film berbasis ampas rumput laut Eucheuma cottonii. Jurnal Teknologi dan Industri Hasil Pertanian.19 (3): 257-273. 